\title{
INFLUENCE OF FOLLICULAR MATURATION AND CULTURE CONDITIONS ON THE MEIOSIS OF PIG OOCYTES IN VITRO
}

\author{
A. TSAFRIRI AND CORNELIA P. GHANNING \\ Department of Physiology, University of Maryland, School of Medicine, \\ 660 West Redwood Street, Baltimore, Maryland 21201, U.S.A.
}

(Received 16th September 1974)

The original finding of Pincus \& Enzmann (1935) that isolated rabbit oocytes will mature spontaneously in vitro has been extended to nine other mammalian species (Donahue, 1972), including the pig (Edwards, 1965; Foote \& Thibault, 1969; McGaughey \& Polge, 1971). The main objectives of the present communication are (a) to describe a culture system for studying the maturation of pig oocytes which can also be used for other ovarian cell types, and (b) to compare the ability of oocytes isolated from follicles differing in their developmental stage to undergo maturation.

Oocytes were collected from pig ovaries obtained at a local slaughterhouse. Within 20 to $30 \mathrm{~min}$ after the pigs had been killed the ovaries were excised and placed in $0.9 \% \mathrm{NaCl}$ plus 100 i.u. penicillin $/ \mathrm{ml}$ and $100 \mu \mathrm{g}$ streptomycin $/ \mathrm{ml}$ at room temperature. Details of oocyte collection, culture, examination and classification have been described elsewhere (Tsafriri \& Channing, 1975). Within 5 $\mathrm{hr}$ after the pigs had been killed, the oocytes were allocated to groups of ten to fifteen and placed in the compartments of an eight-chambered Lab-Tek culture slide (Miles Laboratories, Naperville, Illinois), each compartment containing $0.4 \mathrm{ml}$ culture medium. The medium used was: TC 199 with Earle's salts and 25 mM-HEPES buffer (Grand Island Biological Co., GIBCO, Grand Island, N.Y.) supplemented with $15 \%$ pig serum (GIBCO), glutamine (1 mM, GIBCO) and gentamicin $(50 \mu \mathrm{g} / \mathrm{ml}$; Schering Diagnostics, Port Reading, N.J.). The porcine serum used contained low amounts of $\mathrm{LH}(<1 \mathrm{ng} / \mathrm{ml}$ in terms of NIHovine $\mathrm{LH}$ units), oestrogen $(66 \mathrm{pg} / \mathrm{ml})$ and progesterone $(3 \mathrm{ng} / \mathrm{ml})$, measured as detailed previously (Tsafriri \& Channing, 1975). To this medium (TC 199 plus $15 \%$ pig serum and antibiotics), various amounts of sodium pyruvate (Eastman Organic Chemicals, Rochester, N.Y.), sodium lactate (2.5 mM; Sigma Chemical Co., St Louis, Mo.) and crystalline bovine zinc insulin (Lilly Laboratories, Indianapolis, Ind.) were added (Table 1). Unless mentioned otherwise, the oocytes were cultured for 43 to $48 \mathrm{hr}$ at $37.5 \pm 0.5^{\circ} \mathrm{C}$ in an incubator continuously flushed with air and $5 \% \mathrm{CO}_{2}$ saturated with water. At the end of the culture period, the oocytes were collected, mounted, fixed with alcohol-acetic acid (3:1), stained with aceto-orcein $(1 \%$; GIBCO) and examined microscopically. The stage of meiotic maturation was assessed according to stages described previously (Hunter \& Polge, 1966). The oocytes were divided into three groups: 
immature oocytes with an intact germinal vesicle, mature oocytes that had matured beyond first metaphase, and mature oocytes which had the first polar body and the second metaphase chromosomes. The percentage of oocytes at different meiotic stages in each chamber was calculated and the results were expressed as the mean \pm S.E. of each experimental treatment. Each experimental treatment was repeated in at least two, and usually three or more, independent experiments. An example of fully matured oocytes is shown in Plate 1.

Table 1. Influence of pyruvate, insulin and lactate upon maturation of porcine oocytes grown in medium 199 plus $15 \%$ porcine serum

\begin{tabular}{|c|c|c|c|c|c|c|}
\hline \multirow{2}{*}{\multicolumn{3}{|c|}{ Treatment }} & \multirow{3}{*}{$\begin{array}{l}\text { No. of } \\
\text { oocytes }\end{array}$} & \multicolumn{3}{|c|}{ Mean $\%$ of oocytes $( \pm S . E)}$. \\
\hline & & & & \multirow[b]{2}{*}{ Dictyate } & \multicolumn{2}{|c|}{ Mature } \\
\hline$\underset{(m \mathrm{M})}{\text { Pyrrwate }}$ & $\begin{array}{c}\text { Lactate } \\
(\mathrm{mM})\end{array}$ & $\begin{array}{l}\text { Insulin } \\
(m U / m l)\end{array}$ & & & Total & $\begin{array}{l}\text { With first } \\
\text { polar body }\end{array}$ \\
\hline $\begin{array}{l}0.03 \\
0.03 \\
0.03 \\
0.03 \\
0.03 \\
0.03 \\
0.03 \\
0.03 \\
\overline{-} \\
0.16 \\
0.33\end{array}$ & $\begin{array}{c}\overrightarrow{2 \cdot 5} \\
2 \cdot 5 \\
2 \cdot 5 \\
2 \cdot 5 \\
- \\
25 \\
25 \\
2.5 \\
2.5 \\
2 \cdot 5\end{array}$ & $\begin{array}{l}\text { 二 } \\
1 \cdot 25 \\
12 \cdot 5 \\
125 \\
125 \\
\overline{125} \\
125 \\
125 \\
125\end{array}$ & $\begin{array}{l}40 \\
34 \\
41 \\
42 \\
70 \\
41 \\
36 \\
30 \\
55 \\
42 \\
45\end{array}$ & $\begin{array}{l}19 \cdot 7 \pm 3 \cdot 0 \\
36 \cdot 5 \pm 12 \cdot 8 \\
22 \cdot 0 \pm 4 \cdot 6 \\
12 \cdot 2 \pm 3 \cdot 7 \\
14 \cdot 7 \pm 4 \cdot 9 \\
30 \cdot 9 \pm 4 \cdot 9 \\
56 \cdot 7 \pm 7 \cdot 7 \\
60 \cdot 3 \pm 8 \cdot 4 \\
38 \cdot 1 \pm 5 \cdot 8 \\
28 \cdot 5 \pm 11 \cdot 5 \\
34 \cdot 5 \pm 7 \cdot 9\end{array}$ & 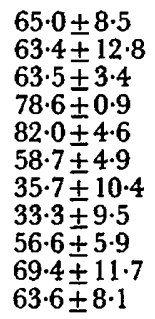 & 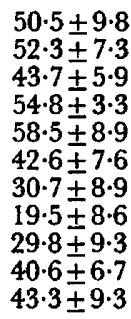 \\
\hline
\end{tabular}

Table 2. Effect of oxygen concentration upon porcine oocyte maturation

\begin{tabular}{|c|c|c|c|c|}
\hline \multirow{3}{*}{$\begin{array}{c}\mathrm{O}_{2} \text { in air } \\
(\%)\end{array}$} & \multirow{3}{*}{$\begin{array}{l}\text { No. of } \\
\text { oocytes }\end{array}$} & \multicolumn{3}{|c|}{ Mean $\%$ of oocytes $( \pm S . E)}$. \\
\hline & & \multirow[b]{2}{*}{ Dictyate } & \multicolumn{2}{|c|}{ Mature } \\
\hline & & & Total & $\begin{array}{l}\text { With first } \\
\text { polar body }\end{array}$ \\
\hline $\begin{array}{l}20 \\
45 \\
95 *\end{array}$ & $\begin{array}{r}102 \\
64 \\
98\end{array}$ & $\begin{array}{l}15 \cdot 9 \pm 3 \cdot 1 \\
36 \cdot 6 \pm 17 \cdot 6 \\
33 \cdot 4 \pm 8 \cdot 6\end{array}$ & $\begin{array}{l}76 \cdot 6 \pm 3 \cdot 9 \\
56 \cdot 6 \pm 16 \cdot 6 \\
53 \cdot 2 \pm 12 \cdot 2\end{array}$ & $\begin{array}{l}52 \cdot 7 \pm 4 \cdot 6 \\
43 \cdot 6 \pm 12 \cdot 8 \\
37 \cdot 5 \pm 8 \cdot 0\end{array}$ \\
\hline
\end{tabular}

In preliminary experiments using the above mentioned medium (without pyruvate, lactate and insulin), of the 237 oocytes isolated from medium-sized ( 3 to $5 \mathrm{~mm}$ in diameter) follicles, $65 \%$ matured beyond first metaphase and only $39 \%$ had the first polar body. The beneficial effects of pyruvate, lactate and insulin upon maturation of such oocytes are presented in Table 1. It is clear that addition of 0.03 mm-pyruvate, 2.5 mm-lactate and 12.5 to $125 \mathrm{mU}$ insulin/ $\mathrm{ml}$ produced optimal conditions for oocyte maturation and in the following experiments, $0.03 \mathrm{~mm}$-pyruvate, $2.5 \mathrm{~mm}$-lactate and $125 \mathrm{mU}$ insulin $/ \mathrm{ml}$ were added. Enriching the culture atmosphere with $\mathrm{O}_{2}$ by flushing large mason jars containing the culture dishes with appropriate mixtures of $\mathrm{O}_{2}$ and air at the 


\section{PLATE 1}

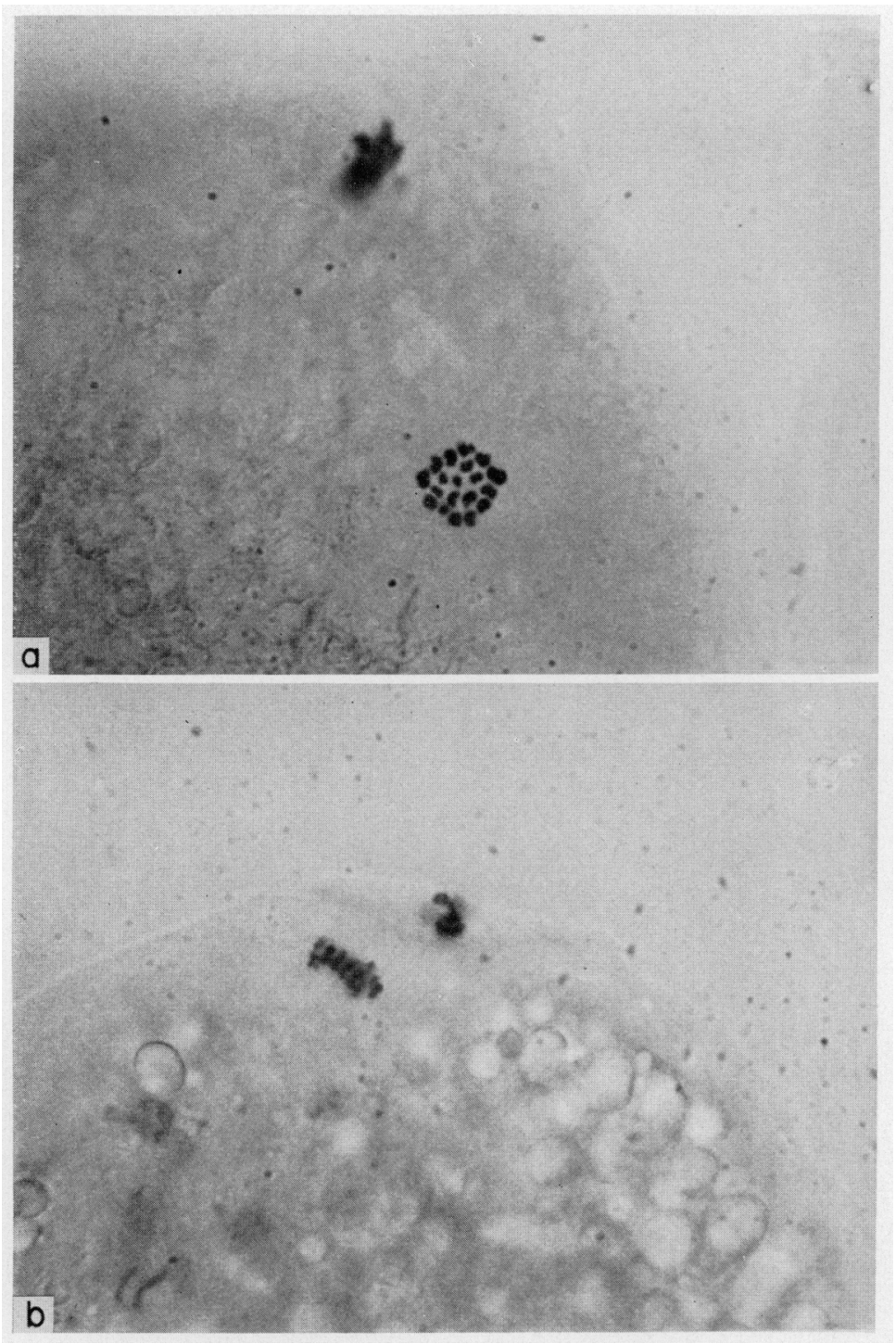

Photomicrograph of porcine oocytes matured in vitro: polar (a) and equatorial (b) view of the metaphase plate. The black mass is the polar body chromatin. Aceto-orcein stain, $\times 1000$. 
beginning of the culture and after $24 \mathrm{hr}$ caused some, but not complete, interference with oocyte maturation (Table 2). It is clear, however, that porcine oocytes were much less sensitive to noxious effects of $\mathrm{O}_{2}$ than are hamster oocytes (Gwatkin \& Haidri, 1974).

There was a graded increase in the competence of oocytes to resume meiosis in vitro according to the stage of follicular growth (Text-fig. 1). While $80 \cdot 1 \pm 2 \cdot 8 \%$ (mean \pm S.E.) of the oocytes isolated from large follicles $(6$ to $12 \mathrm{~mm}$ in diameter) gave off the first polar body, only $54 \cdot 8 \pm 3.3$ and $15 \cdot 6 \pm 5 \cdot 1 \%$ of the oocytes from medium-sized ( 3 to $5 \mathrm{~mm}$ ) and small ( 1 to $2 \mathrm{~mm}$ ) follicles, respectively, completed the first maturation division. Increasing the serum concentration to $50 \%$ was beneficial for maturation of oocytes derived from medium-sized follicles but

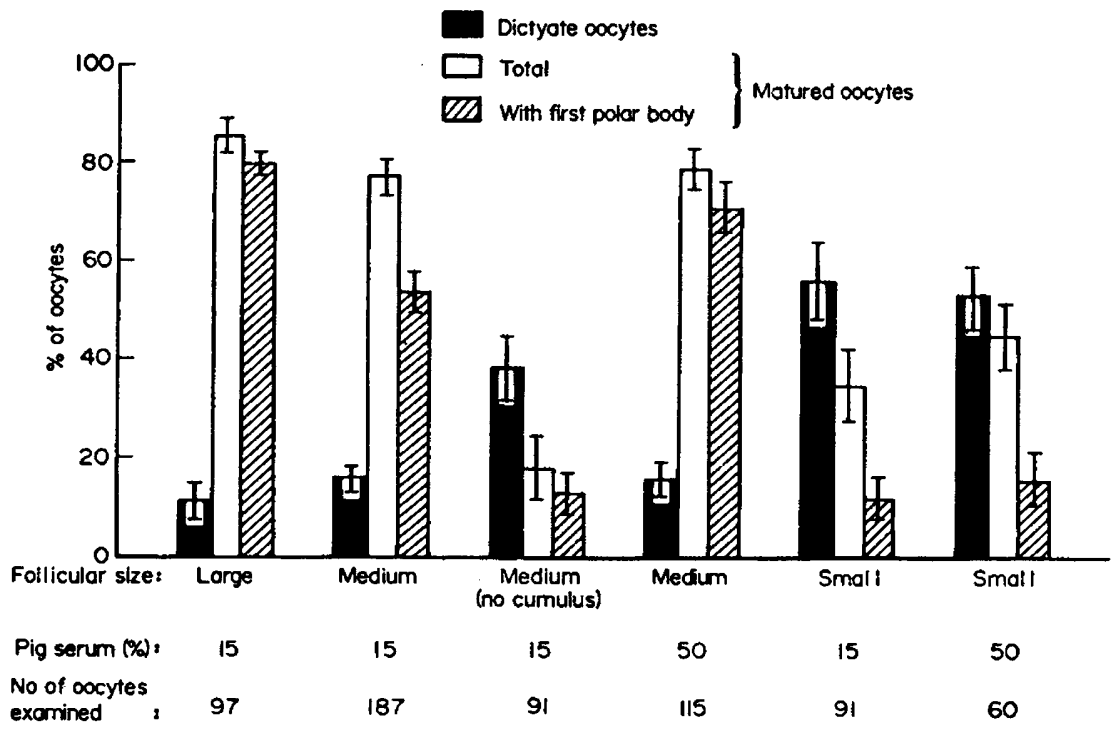

Text-pig. 1. Influence of follicle size upon the ability of isolated porcine oocytes to mature in vitro. Oocytes were harvested from small (1 to $2 \mathrm{~mm}$ ), medium ( 3 to $5 \mathrm{~mm}$ ) and large (6 to $12 \mathrm{~mm}$ ) follicles and were cultured for 43 to $48 \mathrm{hr}$. The vertical bars represent the S.E.M.

not for those from small ones. It is possible, however, that the altered responses in culture of the oocytes from the various follicular sizes represent different nutritional requirements, as has been shown for hamster oocytes (Haidri \& Gwatkin, 1973). The percentage of maturing oocytes depends also upon the developmental stage of the animal: only $46 \%$ of the oocytes isolated from young rabbits matured while all the oocytes from mature oestrous animals matured (Thibault, 1972). In addition, in mouse ovarian explants treated with gonadotrophins, the medium-sized and small antral follicles contained oocytes whose maturation failed to go beyond the dictyate stage whereas large Graafian follicle oocytes usually completed the first maturation division (Neal \& Baker, 1973). Collectively, these findings in pig, rabbit and mouse strongly suggest that not all the fully grown oocytes within the ovary are equally competent to mature. It seems that this competence is attained with follicular growth. The ability of 
granulosa cells to luteinize in culture (Channing, 1970) as well as to bind chorionic gonadotrophin (Channing \& Kammerman, 1973) also increases as the follicle matures. This may indicate that the ability of oocytes to mature and of granulosa cells to luteinize is controlled by similar mechanisms.

The system, employing porcine ovaries collected at the slaughterhouse, from animals at various stages of the oestrous cycle may be very useful for further studies on the physiology of oocyte maturation. Care must be taken to include only oocytes from medium or large follicles and to exclude oocytes found denuded of their cumulus. It is possible that oocytes without their cumulus have been obtained from atretic follicles. It should be emphasized that in the present study (as in most other studies on maturation of oocytes in vitro), only the morphological maturation of the oocyte nucleus was studied. The possibility exists that some proportion of the oocytes might have been degenerating. The best test for physiological maturation would be fertilization and subsequent normal development of the zygote. The possibility of culturing oocytes together with other ovarian constituents can be very useful for further studies on the oocyteovarian cell interrelationships. It has already been shown, utilizing this approach, that granulosa cells cultured with oocytes inhibited the spontaneous maturation of isolated oocytes (Tsafriri \& Channing, 1975).

This study was supported by a grant from the Population Council of New York (M74.52C). One of us (A.T.) is a postdoctoral fellow of the Population Council of New York. The authors thank Ms Viki Tsai, Ms Carol Sakai and Ms Sandra Fowler for their able assistance.

\section{REFERENGES}

Channing, C. P. (1970) Effects of stage of the estrous cycle and gonadotropins upon luteinization of porcine granulosa cells in culture. Endocrinology, 87, 156-164.

Channing, C. P. \& Kammerman, S. (1973) Gonadotropin receptors of porcine granulosa cells during follicle maturation. Endocrinology, 92, 531-540.

Donahue, R. P. (1972) The relation of oocyte maturation to ovulation in mammals. In Oogenesis, pp. 513-538. Eds. J. D. Biggers and A. W. Schuetz. University Park Press, Baltimore.

EDwARDS, R. G. (1965) Maturation in vitro of mouse, sheep, cow, pig, rhesus monkey and human ovarian oocytes. Nature, Lond. 208, 349-351.

Foote, W. D. \& Thibault, C. (1969) Recherche expérimentales sur la maturation in vitro des oocytes de truie et de veau. Annls Biol. anim. Biochim. Biophys. 9, 329-349.

Gwatkin, R. B. L. \& HAIDRI, A. A. (1974) Oxygen requirements for the maturation of hamster oocytes. F. Reprod. Fert. 37, 127-129.

HAIDRI, A. A. \& GWATKIN, R. B. L. (1973) Requirements for the maturation of hamster oocytes from preovulatory follicles. F. Reprod. Fert. 35, 173-176.

HUNTER, R. H. F. \& Polge, C. (1966) Maturation of follicular oocytes in the pig after injection of human chorionic gonadotrophin. J. Reprod. Fert. 12, 525-531.

McGaughey, R. W. \& Polge, C. (1971) Cytogenetic analysis of pig oocytes matured in vitro. 7. exp. Zool. 176, 383-396.

NeAL, P. \& BAKER, T. G. (1973) Response of mouse ovaries in vivo and in organ culture to pregnant mare's serum gonadotrophin and human chorionic gonadotrophin. J. Reprod. Fert. 33, 399-410.

Pincus, G. \& Enzmann, E. V. (1935) The comparative behavior of mammalian eggs in vivo and in vitro. F. exp. Med. 62, 665-675.

Thibault, C. (1972) Final stages of mammalian oocyte maturation. In Oogenesis, pp. 397-411. Eds. J. D. Biggers and A. W. Schuetz. University Park Press, Baltimore.

Tsafriri, A. \& Channing, C. P. (1975) An inhibitory influence of granulosa cells and of follicular fluid upon porcine oocyte meiosis in vitro. Endocrinology (in press). 